\title{
Impact of Relationship Marketing on Customer Loyalty in Banking Sector of Pakistan
}

\author{
NOUMAN SAEED \\ Post-Graduate Scholar, Institute of Management Studies \\ University of Peshawar Pakistan \\ DR. NAIMAT ULLAH KHAN \\ Assistant Professor, Institute of Management Studies \\ University of Peshawar Pakistan. \\ naimatims@yahoo.com
}

\begin{abstract}
This study is a contribution towards marketing literature by analyzing the impact of Relationship Marketing (RM) on Customer Loyalty. Every business organization tries to attract and retain customers for a longer period of time. In recent years an intense competition in banking sector of Pakistan is witnessed as the industry has stretched and become very competitive, where retaining customers in long run become important for every bank. Relationship marketing emphasizes on the continuity of long term relationship with the patrons. Numerous marketing strategies have been employed by banking sector to increase customer base, reduce turn over and to spread positive word of mouth of product and services. The aim of this study is to investigate the impact of relationship marketing practices such as (Trust, Commitment, Communication, Competence and Customer Satisfaction) on customer loyalty in Banking Sector of Pakistan. For this purpose, data is collected with the help of 150questionnaires across Pakistan. Statistical analysis is performed on the data using multiple regression analysis and reliability test. The results of the study show that all the five constructs of relationship marketing (mentioned above) have significant and positive relationship with customer loyalty. The factors are proved to be significant drivers of customer loyalty in banking sector of Pakistan. The study recommends that for retaining long-run customer loyalty, banks should consider relationship marketing as a core strategy. Hence, relationship marketing is important for banks to survive and excel in current intense competition.
\end{abstract}

Key Words: Relationship Marketing, Customer Loyalty, Banking Industry, Pakistan

\section{Introduction}

In past few decades the banking and financial industry has expanded and became very competitive around the globe (especially Pakistan). The product and services offered to customers are rationally uniform. There are enormous challenges for the banking sector to get a competitive advantage among the competitors as sophisticated technologies are reshaping the whole banking industry (Ghaziri, 1998). This can be accomplished through customer loyalty by establishing a long term relationship with the customers, as it is seen as the foremost factor in gaining market share and establishing a 
persistent competitive advantage among the highly competitive financial industry (Afsar et al., 2010). RM is an enduring process concerned with attracting new customers while retaining existing ones. RM significantly helps service based industry to give superior services to customers. Being a service sector, banking industry focuses on providing services to customers with the help of direct marketing and internal marketing. Thus RM is about engagement of customers in long term so as to achieve efficiency in lowering costs and increasing sales (Betty et al., 2012). Similarly Grönroos (1994) defined RM as the basic approach employed by the organizations to establish, sustain and enhance profitable relationship with the patrons while ensuring profitability for both parties involved. Carson et al. (2004) defined RM as activities employed by banks to attract, retain and build long term profitable relationship with the clients. Customer retention means zero defections of high value clients or in simple words no switching. An enduring relationship helps in creating trust and a sense of security among the customers.

According to Gummesson (2008) RM is a new theory based upon relationships that can be blended into traditional marketing practices to produce better results. RM has a positive and direct relationship with customer's loyalty (Shahram et al., 2011). Due to head-on competition, enhanced level of customer loyalty can be achieved through long term relationship (Heffernan et al., 2008). RM is customer focused approach in which an organization established a long term connection with existing and perspective customers (Morgan \& Hunt, 1994). Such a Customer centered strategy should be align with overall aim of improving market productivity and creating profitable relation for the parties involved (Paratiyar et al., 2001).The banking industry across the world is revolutionized and reshaped in terms of technology, intense competition, deregulations and growth in primary product and services demand (Bloemer \& Ruyteranl, 1998). Customers are considered as life line of any business so in order to retain customers for long term, marketers attempted several marketing strategies (Meiden, 1996). Previous studies indicate that retaining customers offer a more persistent and sustainable competitive advantage over attracting new ones for a firm. The overall aim of this study is to analyze relationship between RM practices and customer loyalty in the banking sector. The research suggests different ways to improve quality of service to attract new customers and retain old customers. For this purpose, the study focuses on two questions. (i)Is there any relationship between RM practices and customer loyalty in banking industry? And (ii) Which of the RM practice has more impact on customer loyalty?

\section{Literature Review}

According to Gummesson (2008) RM is a new theory which is based upon relationships that can be blended into traditional marketing practices to produce better results. A new paradigm of marketing and a new focus at the vanguard of service marketing practices. In last two decades RM emerged as a stimulus in the field of marketing, primarily focuses on building long-term relationships with the customers and other stakeholders of business. Customer RM is quickly advancing to become an essential part of Marketing Management Function (Aaltonen, 2004). Carson et al. (2004) defined RM as activities employed by an organization to attract, retain and build long term relationship with the clients. RM is an enduring process concerned with attracting new customers and retaining existing consumers. RM helps service based industry 
significantly so as to give superior services to customers. RM and banking industry performance have an affirmative and encouraging relation. Banking industry as a service based industry focus on providing services to customers majorly by direct marketing and internal marketing thus RM is about engagement of customers in long term so as to achieve efficiency in lowering cost while retaining existing ones (Betty et al., 2012).

According to Ismail (2009) RM stresses that relationship is partnerships with focus on social bonding, joint problem solving and cooperation as centering relationships on common goals. Transaction based marketing situations encompasses a relationship between buyer and seller, such kind of relationship may be narrow in scope and short in duration. While on other hand, relationship developed by RM is long lasting and have more productive outcomes as customer contacts are more frequent and superior service to customers than in transaction marketing (Kotler et al., 2007). RM can be applied at four levels that is technology centered tool of data base marketing, customer retention, customer partnering and at last RMas an integrating everything from database marketing to personalized tailored services, customer loyalty, brand equity and social relationship. RM forms a new level of interaction between the firm and customers (Brodie et al, 1997).

Relationship manager is single point of contact for high net worth clients of retail businesses, to help grow the client financial future update clients regarding their financial need and tailored services according to their needs in order to retain them in long term (commbank.com/careers, 2014). Banking industry is becoming complex, dynamic and aggressive due to radical changes in past few years due to new technologies with low growth in demand, because of lower interest rates and financial crises, deregulation and high competition amongst the financial institutions. Quoting here Government of Pakistan in last decade privatized four out of five big banks operating in country which resulted in increased competition and complexity among them, with increased population of the country and growing economy the increased demand of banking services. Commitment, services quality and customer's satisfaction are important differentiator for gaining customer loyalty and bank success (Bilal, 2010). In this section the most important RM practices are discussed such as Trust, Commitment, Communication, Competence and Customer Satisfaction.Trust is one of the most important practices of RM. Trust can be defined as partner's confidence on integrity of another companion (Morgan et al., 1994). Trust and customer loyalty has affirmative relationship with each other. Abuse of trust may result in customer dissatisfaction (Nudbisi et al., 2005). After trust, commitment is another significant component of building relationship with customers.

Commitment is a worthwhile construct of determining customer loyalty and customer's future buying frequency. Commitment can be defined as a persistent desire to keep long term relationship with customer (Moorman et al., 1992).Communication refers to share and exchange timely information (both formal and informal) between buyers and sellers (Sin et al., 2002). Communication is very important determinant of RM. Retention of customer in long term and customer loyalty demand timely and reliable communication. In this new era of head-on competition and digital world companies cannot excel without it. Interactive communication (two-way) should exist between customer and organization in both before and after sales stages. Communication is all 
about keeping in touch customers with timely and accurate information (Ndubisi, 2007).Competence is defined as client's perception about the seller's technology and commercial capability (Anderson \& Witz, 1989).

Customer would more likely to become a loyal customer with organization in long run if the customer have faith upon the competence of organization. Competency and customer loyalty are positively related to each other. Organization having competitive edge is like to have more loyal customers. Customer satisfaction is a frequently used term in marketing. Customer satisfaction refers to the expectations of customer about products and services of a company. Customer satisfaction reduces customer' complaints, retain customers in long run and avoid negative word of mouth about products and services of a company. For achieving customer loyalty customer satisfaction about the desired product and service is must. Because if the client is not happy than it can led to give up of desired services. Unsatisfied customer cannot be engaged in long run. Achieving customer satisfaction is important practice of relationship marketing. Customer loyalty is persistent, affirmative emotional experience, customer satisfaction and professed value of an experience that includes product and services of a company. Customer loyalty is strong commitment of customer to repurchase frequently and emotional attachment and bond with company (Oliver, 1999).Customer loyalty is all about buyer's commitment and propensity to retain relationship with the seller. Loyal customers are crucial to the success of any business as a small number of loyal customers can result into considerable amount of profitability. Employee motivation and enthusiasm is critical in the RM practices, as employee motivation positively affect customer loyalty, reduced employee resistance and up to mark service can attract and retain customer ( Chen \& Popovich, 2002).

\section{Research Methodology}

A general plan to answer questions that have been raised in the study is called research strategy (Saunders et al, 2000). There are four strategies such as case study, survey, action research and experimental strategy that researcher can adopt to carry out research (Taylor et al., 2006). In this study survey technique is used. Survey is common, attractive and widely used because of high distinction in data collected from individuals in organizations in easier way for researcher to make generalizations. Survey strategy in research normally associated with deductive method. It involves gathering large amount of data from population in an economical way. This research is conducted with the help of different ways including postal, online and self-administered questionnaires(Cooper et al., 2003). In this research questionnaire is distributed across selected bank branches. Some questionnaires are distributed through postal services to selected branches. Some are personally administrated in some nearly accessible branches. In addition along with postal and personally administrated questionaires, online Google forms are used to reach respondents in different geographies in Peshawar region. According to Saunders et al. (2000) sampling can be grouped into two categories: Probability sampling and nonProbability sampling. In this research, non-probability sampling technique is used in which the chances for occurring for all the cases are equal. It is most common type of sampling technique used in survey method. The branches of different banks are chosen randomly, and same number of questionnaires is distributed in each branch. According to 
Dillman (1994) to get high response rate from respondents the questions are concisely and easily explained. In addition, pilot test of the research instrument is done with the help of filling the questionnaire from 10 respondents that are randomly selected from the targeted population. The questionnaire is distributed among target sample as they are representative of the population of banking sector to meet the requirement of the study (Dillon et al., 1993). The researcher is able to get the response of 150 questionnaires from sample bank giving response rate of $83 \%$.

It is important to mention that the questionnaire is adopted from several studies i.e., Beerli et al (2004); Ghana et al. (2006) and Gyasi et al. (2012). ${ }^{1}$ As it is adopted questionnaire, so we assume that there is no issue of validity. First repeated questions are omitted and sequences of questions are altered (the questionnaire is provided in Appendix).Five point Likert scale is used because of small sample size and less time consuming in filling. The questionnaire is divided in many themes i.e., Demographic Questions; Trust Questions; Commitment Questions; Communication Questions; Competence Questions; Satisfaction Questions; Customer loyalty Questions

Regression analysis is used for analysis purpose. The regression model is stated as:

Colayat $(\mathrm{y})=\alpha+\beta_{1} \mathrm{TR}+\beta_{2} \mathrm{COM}+\beta_{3} \mathrm{COMT}+\beta_{4} \mathrm{COMP}+\beta_{5} \mathrm{SAT}+$ error term

Where, Colayat is dependent variable where mean value is used as proxy for customer loyalty. And independent variables for RM are: TR = Trust; $\mathrm{COM}=$ Communication; $\mathrm{COMT}=$ Commitment COMP = Competence; SAT $=$ Satisfaction; $\mathrm{E}=$ Error term In addition, reliability of the various themes is checked with the help of Cronbach Alpha.

\section{Results}

The questionnaires are first sorted out in order to get clean ones, only adequately filled questionnaire are considered. The data is then coded and analyzed. First, descriptive analysis is calculated followed by reliability test, correlation and regression analysis.

\subsection{Demographic Information of Respondents}

Demographic information about respondents is provided in Table 1 in terms of percentages and frequency of occurrence.

Table 4.1: Demographic Analysis $(n=100)$

\begin{tabular}{|c|c|c|c|}
\hline Demographic factor & Item & $\begin{array}{ll}\text { No } & \text { Of } \\
\text { Respondents } & \end{array}$ & Percentage \\
\hline \multirow[t]{2}{*}{ Gender } & Male & 60.00 & $60 \%$ \\
\hline & Female & 40.00 & $40 \%$ \\
\hline \multirow[t]{4}{*}{ Age } & $18-25$ & 18.00 & $18 \%$ \\
\hline & $26-35$ & 48.00 & $48 \%$ \\
\hline & $36-45$ & 26.00 & $26 \%$ \\
\hline & $45-55$ & 8.00 & $8 \%$ \\
\hline \multirow[t]{3}{*}{ Education } & Matric & 8.00 & $8 \%$ \\
\hline & Intermediate & 24.00 & $24 \%$ \\
\hline & Graduate & 54.00 & $54 \%$ \\
\hline
\end{tabular}

${ }^{1}$ Gyasi et al. (2012) did work on this topic in banking sector of Ghana, Lin and Wang. (2006) work in Taiwan market and Beerli et al (2004) studied in Spanish market. 


\begin{tabular}{|llcc|}
\hline & Post Graduate & 12.00 & $12 \%$ \\
Occupation & Illiterate & 2.00 & $2 \%$ \\
& Un Employed & 14.00 & $14 \%$ \\
& Employed & 37.00 & $37 \%$ \\
& Student & 40.00 & $40 \%$ \\
& Businessman & 9.00 & $9 \%$ \\
\hline
\end{tabular}

Table 4.1 shows demographic data of gender, age and education of the respondents. The sample size is of 100 customers of Habib Bank Limited who have maintained their accounts in 17 branches cross Peshawar region. Male respondents were $60 \%$ and female $40 \%$, hence majority of the respondents are male. The male respondent ratio is higher because of Pashtun culture as male is supposed to feed his family. The highest percentages of respondents are from the age group ranging 26-35. The education level of most of respondents is graduate i.e., 54\% of total respondents. The level of education shows that bank customers are mostly educated class.

\subsection{Reliability and Descriptive Statistics}

In the context of this research Cronbach alpha is used to test the reliability of the research instrument. For reliability Cronbach alpha value must be greater than 0.6 (Ahsan et al., 2009). In case of this study all values are higher than 0.6 thus having adequate reliability as shown in Table 2 . In addition, Table 2 shows the mean response of five elements (Trust, Communication, Commitment, Competence and Satisfaction). The mean of all elements show an approximately 4 value. This advocates that on average respondents agree that Trust, Communication, Commitment, Competence and Satisfaction are elements of RM of bank. The lowest standard deviation is of commitment (3.91) while highest is of trust (7.59). The lowest standard deviation means that the respondents have more consensuses in responses regarding commitment factor of RM. While the highest value of standard deviation refers that respondents have diverse view about Trust element of RM.

Table 4.2: Reliability and Descriptive Statistics

\begin{tabular}{|l|l|l|l|}
\hline Factor & Cronbach Alpha & Mean & $\begin{array}{l}\text { Standard } \\
\text { Deviation }\end{array}$ \\
\hline Trust & 0.754 & 4.01 & 0.759 \\
\hline Communication & 0.753 & 4.02 & 0.722 \\
\hline Commitment & 0.702 & 3.99 & 0.391 \\
\hline Competence & 0.722 & 4.00 & 0.688 \\
\hline Satisfaction & 0.773 & 4.22 & 0.641 \\
\hline
\end{tabular}

\subsection{Correlation Analysis}

Correlation Analysis is technique used to measure the strength of relationship between two variables. In case of this research, researcher is interested to measure the degree of association between customer loyalty and independent variables (such as Trust, Commitment, Communication, Competence and satisfaction) to fit a regression model. To how strongly pair of variables is related to each other. Pearson correlation is performed to get the desired results. 
Table 4.3: Correlation Analysis

\begin{tabular}{|c|c|c|c|c|c|c|}
\hline & 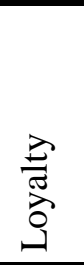 & 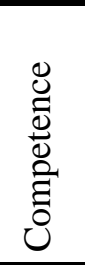 & $\overrightarrow{\tilde{E}}$ & 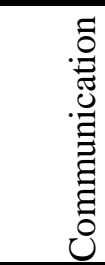 & 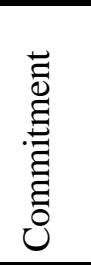 & 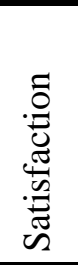 \\
\hline Loyalty & 1.00 & & & & & \\
\hline Competence & 0.52 & 1.00 & & & & \\
\hline Trust & 0.47 & 0.57 & 1.00 & & & \\
\hline Communication & 0.68 & 0.29 & 0.27 & 1.00 & & \\
\hline & 0.75 & 0.61 & 0.29 & 0.77 & 1.00 & \\
\hline & 0.57 & 0.26 & 0.30 & 0.74 & 0.79 & 1.00 \\
\hline
\end{tabular}

In the Table 4.3, correlation is significant at 0.05 levels (2-tailed). In the above matrix Commitment has value of 0.749 which has strong positive correlation with loyalty showing a unit change in commitment has great impact on the loyalty of customer towards a bank. Second most important factor is satisfaction with coefficient value of 0.549; customer satisfaction has high impact on customer loyalty. When customers are satisfied they become loyal customers in long term. Therefore mangers of bank must address the needs and expectations of customers such as by suggesting low interest rates on loans and mortgages, errors free Alternative Delivery Services and comparatively better profit rates on deposits.Once client is satisfied his probability of becoming loyal customer increases (Asfar et al., 2010). Third important RM factor is competence with the coefficient of correlation of 0.517. Bank should provide best technologies and easy access and security to customer deposits and processes. Modern ATM machines, internet and mobile banking with superior quality can attract and retain customers ("Customer Behavior and Loyalty in Retail Banking").The lowest positive correlation value is 0.465 for Trust factor of RM but highly significant (0.000) as well. The results propose that customer loyalty is strongly and positively correlated with RM practices such as Trust, Communication, Commitment, Competence and Satisfaction. 


\subsection{Regression Analysis}

The table below shows regression analysis to determine the impact of five factor of RM on customer loyalty towards their banks.

Table 4.4: Regression Analysis Estimated Coefficients of predicted variables

\begin{tabular}{|llllll|}
\hline Model & \multicolumn{2}{l}{$\begin{array}{l}\text { Unstandardized } \\
\text { coefficients }\end{array}$} & & & \\
& Beta & & t-stats & p-value & VIF \\
& Std.Error & & & & \\
& 1.473 & 0.234 & 3.128 & 0.003 & \\
\hline Constant & 0.686 & 0.057 & 4.81 & 0.020 & 4.70 \\
Trust & 0.643 & 0.058 & 2.58 & 0.004 & 5.89 \\
Communication & 0.672 & 0.071 & 2.78 & 0.003 & 3.23 \\
Commitment & 0.623 & 0.063 & 3.90 & 0.012 & 8.60 \\
Competence & 0.631 & 0.045 & 3.10 & 0.180 & 3.30 \\
Satisfaction & & & & & \\
\hline
\end{tabular}

Table 4.5: ANOVA

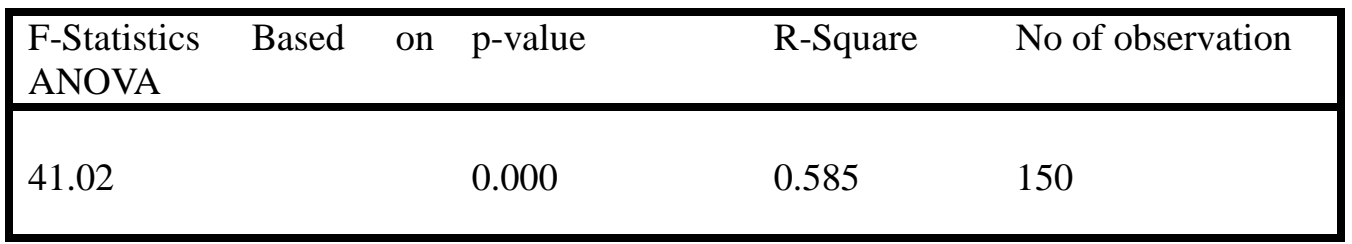

The F-Statistics of 41.02 with $\mathrm{P}=0.000$ shows that the overall model is significant and the five independent variables significantly explain depend variable of customer loyalty. In addition, R-Square value is 0.585 which shows that five RM practices together explain 58.5\% variability in customer loyalty towards bank. Moreover, t-stats give information about the significance of individual independent variable. The results of $t$ statistics show that all five variables (trust, communication; competence, commitment and satisfaction) are significant at 5\% level. ANOVA analysis examines the relationship between the customer loyalty and RM practices. In an effort to estimate how individual factors of RM contributes to customer loyalty in bank, it is documented that trust is prominent driver among five variables towards customer loyalty followed by commitment, communication, competence and satisfaction respectively. The findings also show that trust, communication, competence and satisfaction have significant relationship with loyalty. Customer loyalty in banking industry is a core issue for managers in their lending products, mortgages and deposit mobilizations. In era of head-on competition among various financial institutions, customer's retention is vital for survival of banks. In context of this research, study provides empirical evidence within Peshawar Context that five RM practices (Trust, Communication, Commitment, Competence and Satisfaction) have positive impact on customer loyalty (Kelly et al, 2003). The study determines that $58 \%$ of RM practices contribute to customer loyalty. 


\section{Conclusion}

The attainment of Customer loyalty in banking industry is core issue for the managers in their portfolio management. In current era of head-on competition among various financial institutions, customer's retention in long run is vital for the survival for any bank. This paper investigates the impact of RM practices on customer loyalty in banking sector of Pakistan. This study provides empirical evidence that five RM practices (such as Trust, Communication, Commitment, Competence and Satisfaction) have positive impact on customer loyalty (Kelly et al., 2003). It is concluded from the research that all five variables contribute significantly to customer loyalty and confirm positive relationship with customer loyalty in banking sector of Pakistan. The high degree of practices of RM results in more customer loyalty. Loyal customers spread positive word of mouth and are considered to be key drivers of future of banks. Customer loyalty can be formed, shaped, reinforced and retained with RM practices (Anabila et al, 2012). The finding also suggests that if any bank wants to realize a high rate of customer loyalty, $\mathrm{RM}$ is to be considered by them as their core strategy; a good investment in RM skills can result in a reasonable yield (Narteh, 2009). The major limitation of this study is time and scope. This research also excluded the central regulatory bank, investment and agriculture banks. The study recommends that future research should imply a larger sample size so the findings can be more generally applicable to the banking industry of Pakistan. Future Research on the subject should go beyond banking industry and include investment and financial service providers.

\section{References}

Aaltonen, P. G. (2004). Customer Relationship Marketing and Effects of Demographics and Technology on Customer Satisfaction and Loyality in Financial Services.Diss. Old Dominion University.

Anderson, E. \& Weitz, B. (1989). Determinants of Continuity in Conventional Industrial Channels Dyads. Marketing Science, Vol.8(4) ,PP 310-23

Asfar, B. (2010). Determinents of Customer loyalty in Banking sector of Pakistan. African Journal of Business Management Vol.4 (6), pp. 1040-1047

Beerl,, A., Martin, J. D. \& Quintana, A. (2004). A model of customer loyalty in the retail banking market. European Journal of Marketing, Vol.38(1), pp.253-275

Bloomer, J., Ruyter, K. \& Wetzels, M. (1998). On the relationship between perceived service quality, Service loyalty and Switching Costs. International Journal of industry Management, Vol.9(5), pp.436-53

Brodie, R. J. et al. (1997). Towards a paradigm shift in marketing? An examination of current marketing practices. Journal of marketing management, 13(5), 383-406.

Carson, D., Gilmore, A., \& Walsh, S. (2004). Balancing transaction and relationship marketing in retail banking. Journal of Marketing Management, 20(4), 431-455.

Chen, I. J., \& Popovich, K.. (2003). Understanding Customer Relationship Management: People, Process and Technology. Business Management Journal, 7(5), 374-386.

Cooper, D. R. \& Schindler, P. S. (2003). Business Research Method, Mc Graw-Hill

Ghaziri, H. (1998). Information technology in the banking sector: opportunities, threats and strategies. Retrieved December 17, 2013, from http://almashriq.hiof.no/ddc/projects/business/it-banking.html 
Grönroos, C. (1994). From marketing mix to relationship marketing: towards a paradigm shift in marketing. Management Decision, Vol. 32( 2), pp. 4-20.

Gummesson, E. (2008). Total relationship marketing. $3^{\text {rd }}$ Ed.Boston:Ed.Amsterdam,Heidelbergetc.Elsevier Gyasi, Beauty Esi. Customer Relationship Marketing and Customer Retention: The Perspectives of Customer of Access Bank Ghana Limited. Diss. Institute of Distance Learning, Kwame Nkrumah University of Science and Technology, 2012.

Heffernan, T., O’Neill, G., Travaglione, T. \& Droulers, M. (2008). Relationship marketing: the impact of emotional intelligence and trust on bank performance. International Journal of Bank Marketing, Vol. 26(3), pp. 183-99.

Heffernan, T., et al. (2008). Relationship marketing: The impact of emotional intelligence and trust on bank performance. International Journal of Bank Marketing 26(3), 183-199.

Ismail, S., T. (2009). The effects of relationship marketing on organizational outcomes. An applied study in Jordanian Insurance Companies. European Journal of Social Sciences 12(2), 176-184.

Kotler, P., \& Keller, K. L. (2007). Marketing management, Pearson education.

Meidan, A. (1996). Marketing Financial Services, Macmillan Press, Houndmills.

Meler, M. (2002). A marketing Approach to Creating Clients in Tourism and the Hotel Industry. International Journal of Contemporary Hospitality Management 14.6 274-285.

Moorman, C., Zaltman, G. \& Deshpande, R. (1992). Relationships between providers and users of market research: the dynamics of trust within and between organizations. Journal of Marketing Research, 29( 3), 314-328.

Morgan, R. M. \& Hunt, S. D. (1994). The commitment-trust theory of relationship marketing. Journal of Marketing, Vol. 58(3), pp. 20-38.

Morgan, R. M. \& Shelby, D. H. (194). The commitment-trust theory of relationship marketing. The journal of marketing, 20-38.

Narteh, B. (2009). Relationship Marketing and Customer Satisfaction in the Ghanaian Banking Sector. Journal of retail marketing management research, 2(1), 15-29.

Ndubisi, N. O. (2005). Effect of gender on customer loyalty: a relationship marketing approach. Marketing Intelligence \& Planning, Vol. 24(1), pp. 48-61.

Ndubisi, N. O. \& Chan, K. W. (2005). Factorial and discriminant analyses of the underpinnings of relationship marketing and customer satisfaction. International Journal of Bank Marketing, Vol. 23(3, pp. 542-57.

Ndubisi, N. O. (2007). Relationship marketing and customer loyalty, Marketing Intelligence \& Planning, 25(1), pp.98-106

Oliver, R. L. (1999). Whence consumer loyalty? Journal of Marketing, Vol.63,pp.33-44

Parvatiyar, A.,Shheth, J. N. (2000). The Domain and Conceptual Foundation of relationship marketing. IN J.N.Sheth \& A. Parvatiyar (Eds.), Handbook of Relationship marketing,(3-38).

Peter, A., Dr.Bedman, N. \& Ernet,Y. (2012). Relationship Marketing Practices and Customer loyalty: Evidence from the banking industry in Ghana Vol.4(13). 
Saunders, M. L. \& Thornhill, A. (2000). Research Methods for business Students.England: Printhall

Shahram, G., Taleghani, M. \& Mousavian, S. J. (2011). The Role of Relationship marketing in customer oreinatation process in the banking industry with foucus on loyalty. Vol.2(19). pp:1.

Sin, L. Y. M., Tse, A. C. B., Yau, O. H. M., Lee, J. S. Y. \& Chow, R. (2002). The effect of relationship marketing orientation on business performance in a service oriented economy. Journal of Service marketing, 16(7): 656-676.

Walsh, S., Audrey, G. \& David, C. (2004). Managing and implementing simultaneous transaction and relationship marketing. International Journal of Bank Marketin, 22(7), 468-483. 


\section{APPENDIX: QUESTIONNAIRE}

"Impact of Relationship Marketing on Customer Loyalty"

Dear respondent, this questionnaire is designed to know your opinion related to your loyalty to commercial banks. Your precious time is needed to answer the questions in the following questionnaire which is intended for academic purpose, information should be provided with attention, experience and confidentiality. Your help can play decisive role in completion of this study. Do try all the questions and mark on the respective appropriate box. Your sincere contribution will be very much appreciated.

\section{RESPONDENT' INFORMATION}
a) GENDER:
$\square$ Male
b) Age:
$\square$ 18-25
$\square$ Female
$\square$ प 46-55
$\square 26-35$
$\square 36-45$
c) Education:
$\square$ Matric
$\square 56$ and above.
$\square$ Post Graduate
$\square$ illiterate
d) Occupation:
$\square$ Intermediate $\square$ Graduate
$\square$ Un Employed $\square$ Employed $\square$ Student
$\square$ Business person If others, please mention _-

\section{e) Bank Customer For}

$\square$ Less than year
$\square$ More than 5 years

\begin{tabular}{|c|c|c|c|c|c|}
\hline Trust & $\begin{array}{l}\text { Strongly } \\
\text { Agree }\end{array}$ & Agree & Neutral & Disagree & $\begin{array}{l}\text { Strongly } \\
\text { Disagree }\end{array}$ \\
\hline \multicolumn{6}{|l|}{ Bank Has High Integrity } \\
\hline \multicolumn{6}{|l|}{ Bank Has Good will Reputation } \\
\hline \multicolumn{6}{|l|}{ Consistent in Unique service providing } \\
\hline \multicolumn{6}{|l|}{ Bank is Trust worthy } \\
\hline Commitment & $\begin{array}{l}\text { Strongly } \\
\text { Agree }\end{array}$ & Agree & Neutral & Disagree & $\begin{array}{l}\text { Strongly } \\
\text { Disagree }\end{array}$ \\
\hline \multicolumn{6}{|l|}{$\begin{array}{l}\text { The services are provided by the bank at the } \\
\text { settled timings to me }\end{array}$} \\
\hline \multicolumn{6}{|l|}{ Feel bank is looking out for my interests } \\
\hline \multicolumn{6}{|l|}{$\begin{array}{l}\text { Bank team understand the exact needs of } \\
\text { the customer }\end{array}$} \\
\hline \multicolumn{6}{|l|}{ Bank Fulfill that it promises } \\
\hline Communication & $\begin{array}{l}\text { Strongly } \\
\text { Agree }\end{array}$ & Agree & Neutral & Disagree & $\begin{array}{l}\text { Strongly } \\
\text { Disagree }\end{array}$ \\
\hline \multicolumn{6}{|l|}{ Staff Communicates in Friendly manner } \\
\hline \multicolumn{6}{|l|}{$\begin{array}{l}\text { The required information is delivered and } \\
\text { obtained easily }\end{array}$} \\
\hline \multicolumn{6}{|l|}{$\begin{array}{l}\text { Electronically messages delivered are very } \\
\text { supportive }\end{array}$} \\
\hline The bank stay in contact persistently & & & & & \\
\hline
\end{tabular}




\begin{tabular}{|c|c|c|c|c|c|}
\hline Competence & $\begin{array}{l}\text { Strongly } \\
\text { Agree }\end{array}$ & Agree & Neutral & Disagree & $\begin{array}{l}\text { Strongly } \\
\text { Disagree }\end{array}$ \\
\hline \multicolumn{6}{|l|}{$\begin{array}{l}\text { Bank ATM machine are user friendly and } \\
\text { easily accessible }\end{array}$} \\
\hline \multicolumn{6}{|l|}{ Bank has largest branch network } \\
\hline \multicolumn{6}{|l|}{$\begin{array}{l}\text { Bank Alternate delivery channels are better } \\
\text { than other }\end{array}$} \\
\hline \multicolumn{6}{|l|}{ Bank services are better than other banks } \\
\hline Satisfaction & $\begin{array}{l}\text { Strongly } \\
\text { Agree }\end{array}$ & Agree & Neutral & Disagree & $\begin{array}{l}\text { Strongly } \\
\text { Disagree }\end{array}$ \\
\hline \multicolumn{6}{|l|}{ Bank completely meets my expectation } \\
\hline \multicolumn{6}{|l|}{ Bank completely meets my expectation } \\
\hline \multicolumn{6}{|l|}{ Completely satisfied with all bank services } \\
\hline \multicolumn{6}{|l|}{ Employee Work in Tidy Professional way } \\
\hline Loyalty & $\begin{array}{l}\text { Strongly } \\
\text { Agree }\end{array}$ & Agree & Neutral & Disagree & $\begin{array}{l}\text { Strongly } \\
\text { Disagree }\end{array}$ \\
\hline \multicolumn{6}{|l|}{ I intent to use bank services for long time } \\
\hline \multicolumn{6}{|l|}{$\begin{array}{l}\text { Even if another bank provide services at } \\
\text { lower cost I will stay with bank }\end{array}$} \\
\hline \multicolumn{6}{|l|}{$\begin{array}{l}\text { I am willing to say positive things to other } \\
\text { customer }\end{array}$} \\
\hline $\begin{array}{l}\text { I will encourage other people to use the } \\
\text { bank services. }\end{array}$ & & & & & \\
\hline
\end{tabular}

